\title{
"In memory of victims": Monument and counter-monument in Liberty Square, Budapest
}

\author{
ÁgNES ERŐSS ${ }^{1}$
}

\begin{abstract}
Conceived by the Hungarian government as a commemoration of the German occupation of Hungary and according to the inscription dedicated to the "memory of victims", the monument in Liberty Square has been a scene of protest against a prominent emblem of the right-wing Hungarian government. The protest has taken the form of a counter-monument that contests the official meanings of the government-sponsored composition and especially the notion it conveys depicting Hungary as a victim of German occupation. Whereas the official monument evokes traditional forms and its aesthetic is neo-classical, the counter-monument consists of ephemeral features such as gradually accumulated written messages and everyday artefacts, and it is constantly built up by protesters. The counter-monument not only challenges the adjacent official monument and its notion of Hungary as a victim of German occupation; importantly, it defies the legitimacy of the official conception of victimhood by direct references to the suffering of Hungarian Jews at the period. This paper explores the politics of commemoration at the contested memorial site with an emphasis on the dialectic relationship between the official monument and an adjacent counter-monument. Focusing on a contemporary case-study in the centre of the Hungarian capital, it offers insights into resistance and protest as geospatial features of the politics of public memory.
\end{abstract}

Keywords: monument, counter-monument, politics of commemoration, public space, contested space

\section{Introduction}

Imagine a square, encircled with magnificent historic buildings, palaces, tenement blocks, banks, insurance companies, and exclusive offices. Elegantly dressed managers passing by while children are playing in the shadow of old trees. Such scenery is not unusual to European cities. However, if one considers that in that particular square there is an extravagant triangle formed by a life-size statue of Ronald Reagan, a monument of Soviet soldiers and the heavily fortified US Embassy, then we arrived at the Liberty Square, to the heart of Budapest (Figure 1).

The configuration of edifices is the most striking visible example of the dense and multi-layered symbolic geography of the centrally located square of the Hungarian capital. This square has been subjected to a series of symbolic space appropriation campaigns executed by consecutive political powers in the last two hundred years.

At the beginning of the $19^{\text {th }}$ century the territory of today's square was partially occupied by an enormous building where numerous political prisoners, emblematic figures of the anti-Habsburg Hungarian revolution and war of independence in 1848-49 were executed or imprisoned. During the AustroHungarian Monarchy, the prison, also known as the 'Hungarian Bastille', was demolished. As a remnant of revolutionary spirit, the surrounding streets were named after victims of the freedom struggle against Habsburgs, while the square was baptised as Liberty Square (Szabadság tér).

In the interwar period, often referred to as Horthy era (after Miklós Horthy, governor of Hungary between 1920 and 1944), new stat-

\footnotetext{
${ }^{1}$ Geographical Institute, Research Centre for Astronomy and Earth Sciences, Hungarian Academy of Sciences, H-1112 Budapest, Budaörsi út 45. E-mail: eross.agnes@csfk.mta.hu.
} 


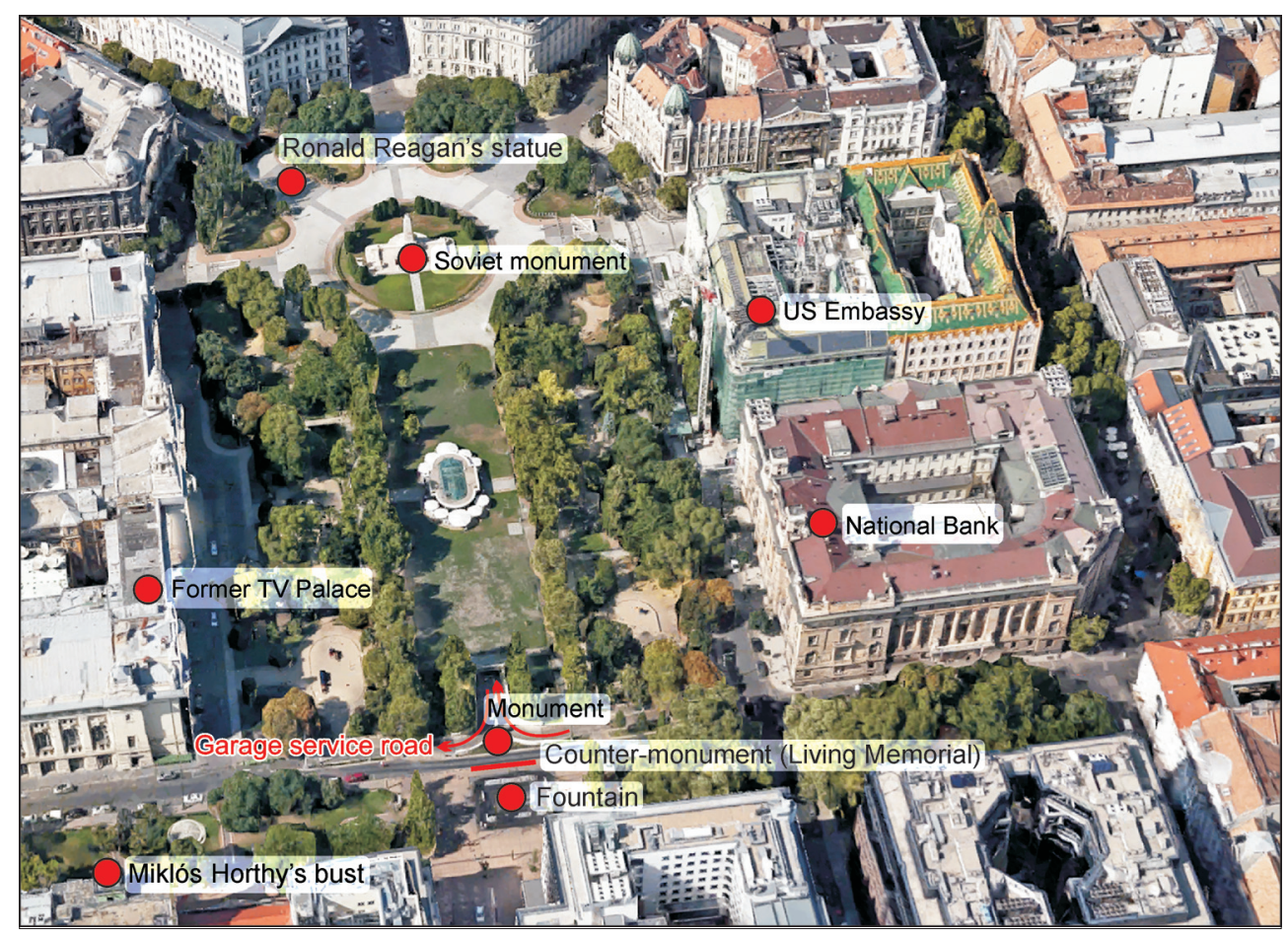

Fig. 1. Overview of Liberty Square (Szabadság tér), Budapest

ues and grandiose monuments symbolising the territories Hungary lost following World War I were installed composing a powerful and dramatic facade for regular irredentist events (ZeIDLER, M. 2007, 188-211). Not surprisingly, when the Red Army captured Budapest in 1945, the statues, as reminders of Hungarian nationalism and the previous Horthy era, were replaced to make room for the monument dedicated to the Soviet soldiers who lost their lives while fighting the Nazi military forces to liberate (as it was phrased for decades after) the Hungarian capital.

Following 1990, even though there was a debate about it, the Soviet memorial remained untouched (Fооте, K. et al. 2000, 324-325). Unveiling the statue of Ronald Reagan in 2011, who is perceived by many as liberator of the countries beyond the Iron Curtain, further enriched the symbolic interpretation of liberty on the square. On the South side of the square, a Bauhaus building houses a Calvinist church. Its name, Church of Homecoming, commemorates the $1^{\text {st }}$ Vienna Award which rewarded Hungary the Southern part of Czechoslovakia in 1938. It was celebrated as great achievement of irredentist politics of the Horthy era. On the $75^{\text {th }}$ anniversary of the Vienna Award, a bust of Miklós Horthy was inaugurated in the open staircase of the Calvinist Church, supported by right-wing Jobbik, the third biggest political party in the country. Even though the irredentist statues disappeared from the square, today the church and the bust stand as mementos of the interwar period.

Nevertheless, the contemporary history of the square was not without violence: in 2006 anti-government protesters besieged the seat of Hungarian National TV located on the West side of the square. The rally was ended by a brutal police response.

As a result of aforementioned symbolic political manoeuvres, today the square is packed 
with historically and politically engaged monuments, spatial mnemonics of different regimes. Memories of mass-protests in support of different political ideas and powers juxtaposing various narratives of freedom and notions of liberty. The most recent element of the setting, dedicated to the victims of German occupation in Hungary in 1944, was installed in 2014. Ever since the artistic plan was published there has been an ongoing protest against it in various forms of resistance that culminated in the installation of a counter-monument, which is discussed in the present article.

\section{Monuments, counter-monuments, living memorials}

Monuments and politics of commemoration have been in the focus of scientific interest, including human geography in the last decades. According to one, simple definition, a monument is built to "induce remembrance of specific events or people" (Gregory, D. et al. 2009, 478). Monument-building has been a hallmark of modern nationalism and formation of modern nation states. A series of studies has thoroughly illustrated that monuments - next to other tools, for instance (re)naming streets - are applied by power to occupy public space in order to inscribe its specific narrative about the past, in many cases justifying its authority in the present (NorA, P. 1989; Till, K. 1999; Light, D. et al. 2002; Foote, K. and Azaryahu, M. 2007; Palonen, E. 2008; Rose-Redwood, R. 2008; HobsBawn, E. 2015).

While in the $19^{\text {th }}$ century heroic, figurative statues were preferred for celebrating national ideas and icons, in the late $20^{\text {th }}$ century a major turn can be detected in the artistic comprehension and design of monuments. More and more artists found that traditional monuments "may only displace memory" reducing visitors to simple spectators instead of enhancing memory work of individuals and society. That notion induced the proliferation of counter-monuments - antiheroic in content, the figures rather conceptual
- which can be understood as "memorial spaces conceived to challenge the very premise of the monument" (Young, J.E. 2000, 96).

The abstract aesthetics and non-traditional visualisation can be detected in case of national memorials as well, where the counter-monumental design is perceived as more appropriate to challenge the traditional ideas of nation, "mark the national ambivalence and uncertainty of late twentieth-century postmodernism" (Young, J.E. 2000, 93). As Strakosch, E. (2010, 268) argues: "Instead of presenting a simple story of triumph or martyrdom, they (i.e. counter-monuments) confront the nation-state with its own crimes and exclusions".

Alternative forms of commemoration show great variety and resulted in mushrooming of different terms, like counter, non-traditional or non-monument. In their thorough article, Stevens, Frank and Fazakerley (2012) introduce a system to bring more clarity to discussions on counter-monuments. According to their opinion, on the one hand, monuments can adopt counter-monumental design which aim is "to express subjects and meanings not represented in traditional monument" in any of five respects: subject, form, site, visitor experience and meaning. On the other hand, a monument can carry dialogic message in which case it "critiques the purpose and the design of a specific, existing monument, in an explicit, contrary and proximate way" (STEvens, Q. et al. 2012, 952). The spatial position of a dialogic monument is also important, as it is often "(...) intentionally juxtaposed to another, pre-existing monument located nearby and that critically questions the values the pre-existing monument expresses" (Stevens, Q. et al.2012, 962). In contrast to traditional monuments, counter-monuments offer no clear and simple answers; they rather invite visitors to actively engage with the monument using all five senses and let those experiences help them to find their own interpretations (Young, J.E. 2000, 120-139).

The act of memorialisation and practices of commemoration has also entered every 
day settings of life. As SHANken described, so-called living memorials often take place in secular and utilitarian places "(...) drawing memorialisation closer to leisure, recreation, and the desire for cohesive community" (Shanken, A.M. 2002, 132). A flashmob in public space can be understood as living memorial, when certain part of space becomes temporarily occupied by a - for instance - commemorative art performance. Living memorials might distance themselves from the dominant way of remembering, but not necessarily question the narrative of the event or the person commemorated, if they do at all. To conclude, the major purpose of a counter-monument is to reject or renegotiate the original monument applying unconventional design, inviting visitors to use their senses to discover meanings and create their individual interpretation of commemorated events or persons.

In this paper it is argued that the official monument commemorating the victims of the German occupation of Hungary exemplifies the earlier traditions of monument design lacking intention of facing the past in a critical or self-reflected way, offering only one narrative of the past. However, the juxtaposed counter-monument, called Eleven Emlékmü (Living Memorial) not merely challenges the design, but the narrative of the official monument.

After drafting the political context, I offer a brief historiography of the installation of the monument and outline the major points of critique. This would help to understand the protest it evoked which takes the form of a physically tangible, ever changing and enlarging counter-monument and a discursive space, where open discussions and cultural events are organised by civic and political activists.

The main purpose of the paper is to show how the installation of a monument, an attempt of the power to gain visibility in a symbolically distinguished place, provokes civic protest which - by erecting a counter monument - find a new channel of self-expression and representation.

\section{Political context}

In 2010 the right wing-conservative Fidesz party won the parliamentary elections in Hungary. The landslide victory, which was soon to be named as "revolution at the polls" (PAlonen, E. 2012, 947) enabled politicians of the ruling party to obtain fundamental changes in various fields of the legal, social and economic life of the country. Among others a new constitution, an electoral reform, and new media law (e.g. forcing journalists to reveal their sources) were accepted (PALONEN, E. 2012, 947-951). Not only the new laws, but also the peremptory way how those went through the legislation process prompted protests. Even though from time to time thousands of people rallied on streets (VÁRNAGY, R. 2013), or supported the opposition movements by joining their Facebook sites, after couple of months the intensity decreased and the number of active supporters dramatically fell. In 2013, less than a year prior to the next elections, Prime Minister Viktor Orbán openly voiced his opinion that liberal democracy is failing, and the constitution - in power since 2012 - is consequently "non-liberal, but a national one" (Orbán, V. 2013).

Fidesz not only transformed the legal basis of the country, but also made tremendous efforts to imprint the beginning of a new era of political history on the symbolic landscape. Actually, symbolic politics was already a major element of the toolkit of the first Fidesz government (1998-2002). When analysing three architectural projects (including the new National Theatre) launched during the first governing period of Fidesz, Emilia PALONEN found that "The cultural institutions and their architectural forms became a tool for Fidesz to manifest its vision (...) for the future and inscribing readings of the past, definitions of the nation" (PAlonen, E. 2013, 548-549).

Symbolic politics remained important part of the politics of Fidesz when it came into power again in 2010: extensive renaming of public spaces commenced replacing foreign names with Hungarian ones and purging 
potential leftist persona from the cityscape. Among the newly re-baptised street names or novel statues political and cultural figures of the conservative political traditions, primarily from the interwar Horthy era appeared, supporting the opinion that even though the nationalism of Fidesz was less radical as of the far right party called Jobbik, in order to "maximise votes they also sought to integrate some of the rhetoric of the right, including some references to anti-Semitism" (PALONEN, E. 2012, 947). The fact that the name of the country was changed from Hungarian Republic to Hungary or the Republic Square in the middle of Budapest was re-baptised after Pope John Paul the Second might be perceived as further elements of a nationalconservative turn sympathising with illiberal political traditions and the controversial figures of the Hungarian conservative tradition from times of the Austro-Hungarian Monarchy or the Horthy era.

The reconstruction of Kossuth Square, the political centre of the country dominated by the magnificent building of the Parliament, offers another example of the symbolic politics pursued by Fidesz aiming to reinstall certain elements of public space that had been created in the interwar Horthy era. The Kossuth Square was envisioned to gain back the "artistic face of the square prior to 1944", thus, three monumental statues that stood there prior to World War II but had been removed after 1945, were re-created. ${ }^{2}$ Furthermore, opposite to the Parliament, a national flag was installed on a $33 \mathrm{~m}$ tall flagpole, which can be perceived as a clear reference to a previous flagpole, called National Banner installed in the nearby Liberty Square in 1928 as a central piece of the irredentist monument (DӧмӧтӧRFI, T. 1991). Reconstruction of Kossuth Square was not even finalised, when the government decree about installing a new monument on Liberty Square, proved to be symbolically so important for political powers in the modern history of this country, was announced.

\footnotetext{
${ }^{2} \mathrm{http}$ ://latogatokozpont.parlament.hu/en/a-kossuthter-leirasa
}

\section{History of the monument}

The government decree was issued on the very last day of $2013^{3}$. It ordered the construction of a monument dedicated to victims of German occupation. The decree refers to the approaching $70^{\text {th }}$ anniversary of the occupation and marked the deadline of finalisation of the construction on $19^{\text {th }}$ March 2014. The government decree declared the project an issue of particular importance with regard to the national economy, thus, the implementation could start without obtaining official expert statement of - for instance - landscape committee and the construction company was commissioned without a tender. Similarly, (according to the official explanation due to the short deadline) the artist was directly appointed by the minister responsible for the implementation of the project ${ }^{4}$.The concept plan of the monument was presented and accepted as early as mid-January and was only approved by a five-member committee. The project documentation were first made public on $19^{\text {th }}$ January in a blog post written by Tibor PÁszTor, a representative of opposition party in the $5^{\text {th }}$ district of Budapest. As the owner of the land, the local government had to give permission for the construction.

Right after the plan became public on $19^{\text {th }}$ January, at first leaders of the Hungarian Jewish communities raised their voice against it, soon followed by historians, art historians, artists, politicians, NGOs and concerned individuals inside and outside Hungary. According to the objections, the interpretation of the monument relativises the responsibility of the then Hungarian government, state administration and armed forces which played an active role in execution of the Holocaust of nearly half a million Hungarian Jews (Pethô, T. 2014; UngváRY, K. 2014). The intensive criticism most probably contributed to the decision of the Prime Minister to suspend the construction until $31^{\text {st }}$ March. Additionally, he showed open-

\footnotetext{
3 2056/2013. (XII. 31.) Government decree. Magyar Közlöny, 2013/225. 31.12.2013.

${ }^{4}$ PÁsztor, T. 2014.
} 
ness to enter into discussion about the statue with representatives of Jewish organisations. However, two days after the Fidesz victory in the parliamentary elections, on $8^{\text {th }}$ April, the construction was restarted without any notification (FeHÉr, M. 2014a). Eventually the last parts of the monument were put into place on $20^{\text {th }}$ July, during the night (Nolan, D. 2014). Events of the ongoing protest were extensively covered by international and national media (LALONDE, I. 2014; Newton, C. 2014 $)^{5}$. Notably the monument has never been officially inaugurated ${ }^{6}$ and it has never been used in any official ceremony or commemorative event.

Remarkably, since March 2014, when the protest against the monument manifested itself in public space, a counter-monument compiled from personal relics, stones, photos, eviction notices has been established at the thin strip of the pavement right opposite to the official monument. Such visual resistance is strengthened by the presence of protesters, who organise regular public talks and cultural events around the counter-monument. Altogether, the monument gave immediately birth to a counter-monument and to an active opposition which has become the longest prevailing regular opposition movement against the Orbán Government. Controversies about monuments are not uncommon and mostly "pertain to their commemorative theme and/or artistic design" (Azaryhu, M. 2011, 131). In the present case study I argue that in the case of the monument dedicated to the victims of German occupation in Liberty Square in Budapest, the above mentioned two elements are present at the same time and their joint impact is enhanced by the authoritarian decision-making mechanism of Fidesz after 2010.

\footnotetext{
${ }^{5}$ http://www.foxnews.com/world/2014/07/20/inmiddle-night-hungary-sets-up-disputed-memorialto-144-german-occupation/; http://www.jta. org/2014/04/08/news-opinion/united-states/amidprotest-building-of-controversial-wwii-statuebegins-in-budapest.

${ }^{6}$ http://www.kormany.hu/hu/miniszterelnokseg/ hirek/nem-lesz-avatounnepseg
}

\section{The iconography of the monument and major points of critique}

The state monument was designed by Péter Párkányi Raab, whose previous works were installed around the National Theatre, which is one of the major symbolic constructions during the first Fidesz government (PALONEN, E. 2013, 547). The composition standing on the southern end of the Liberty Square comprised by two main figures: an eagle, symbolising Nazi Germany and an angel as a representation of Hungary standing in front of the colonnade topped with a tympanum. According to the artist's project documentation (which is not without misspellings and presents only sketches of the monument): the composition is an allegory displaying the battle between "two cultures", where the eagle is brutal and aggressive while Archangel Gabriel stands still, and serene. His face gesture depicts suffering while the orb falling from his hand symbolises losing power, control over Hungary ${ }^{7}$. Under the tympanum the following is inscribed: "Monument dedicated to the victims of German occupation". In an additional element attached to the monument with a text written in four languages (Hungarian, English, German and Hebrew) is corked: "In memory of victims" (Photo 1).

Critiques concerned three major issues: the monument's spatial position, aesthetics and most importantly its symbolisation and historical narrative. Regarding the aesthetics and especially the location of the monument opinions were more or less unequivocal, and far from flattering. Nevertheless, both were dwarfed by the outcry over its content and symbolisation.

\section{A place not meant to be for a monument}

Liberty Square has acquired prime position among the politically employed public spaces in Budapest. Consequently, a suitable location for a new monument in the already crowded

\footnotetext{
${ }_{7}^{7}$ Pásztor, T. 2014.
} 


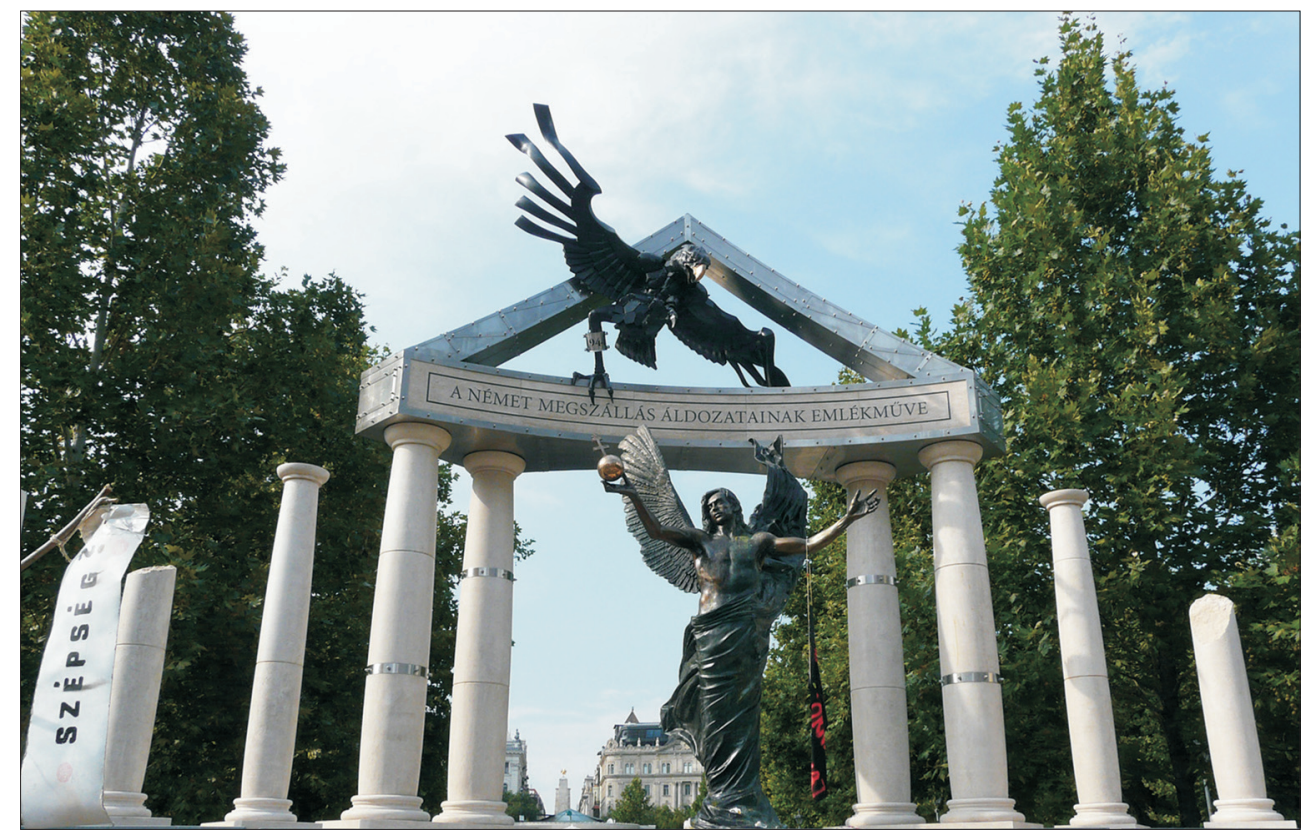

Photo 1. Main figures of the monument: the eagle and Archangel Gabriel. In the background the top of the Monument of Soviet soldiers. (Photo by the author)

square with dense symbolic charge poses a serious challenge. The monument (designed to only face one angle, the South) is placed on the south side of the Liberty Square, squeezed in between a service road of an underground garage and a narrow road with one-way car traffic (Photo 2). The unfortunate position impedes potential visitors who would wish to stands close to it, while stepping back is also not helpful, as the south end of the square is closed by a fountain, which partially blocks the view and definitely attracts the attention of visitors, especially in hot summer days (Photo 3). Consequently, for potential visitors the monument is not welcoming.

According to Péter György, aesthete, the idea behind choosing such location could have been to countervail the Soviet monument which stands on the northern side of the square. Although, the new monument fails to fulfil this hypothetical role as the Soviet monument, with a shape of an obelisk, is not only accessible from all directions, but it offers something new to look at for the visitor who is walking around it from every angle (Czenkli, D. 2014) (Photo 4).

At an early stage of the protest there were fears voiced that far right activists might use the road connecting the monument to the bust of Horthy, placed on the south-western edge of the square to rally. Finally, the most striking disadvantageous feature of the monument cannot be missed by visitors less educated in arts either: the seven meter tall composition, equipped with figurative elements and massive columns was installed onto such a little piece of land which is simply not suitable for a monument at all, especially to a national monument.

\section{"Messy nightmare": Critics of aesthetics}

Following 1989, among the newly installed monuments in Budapest commemorating, for instance, the 1956 Revolution examples 


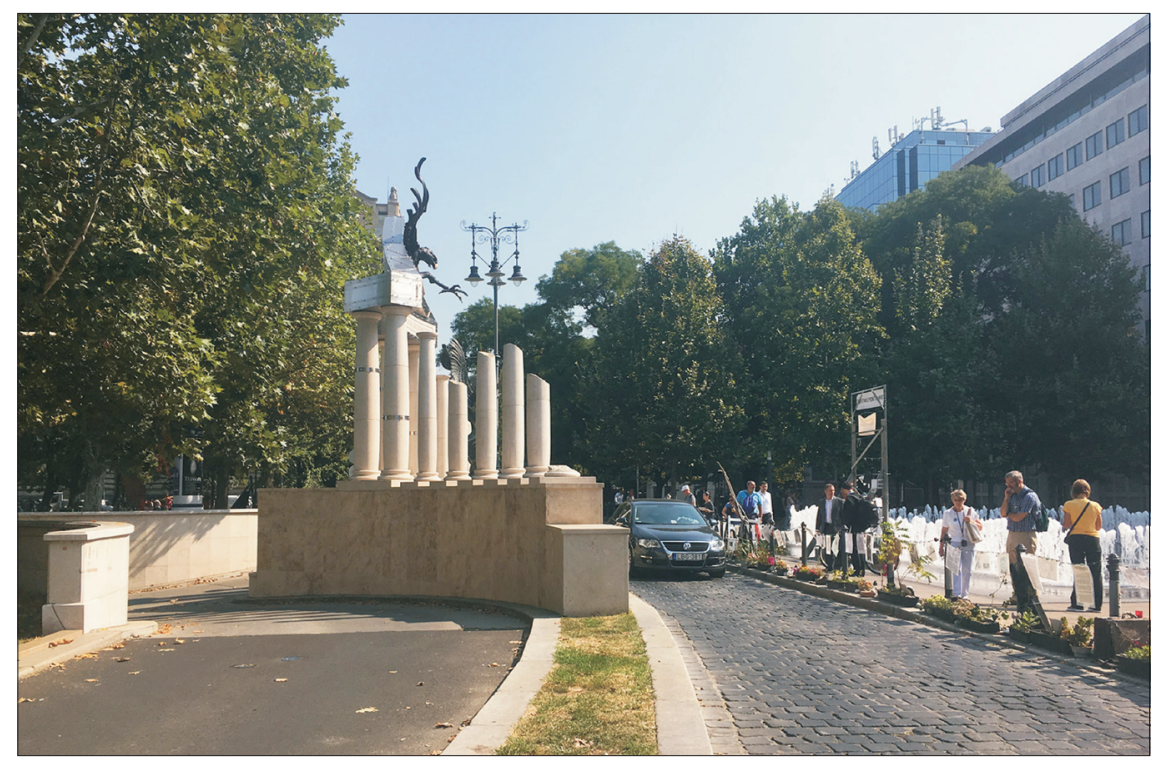

Photo 2. The monument standing in a little piece of land, squeezed in between roads. (Photo by the author)

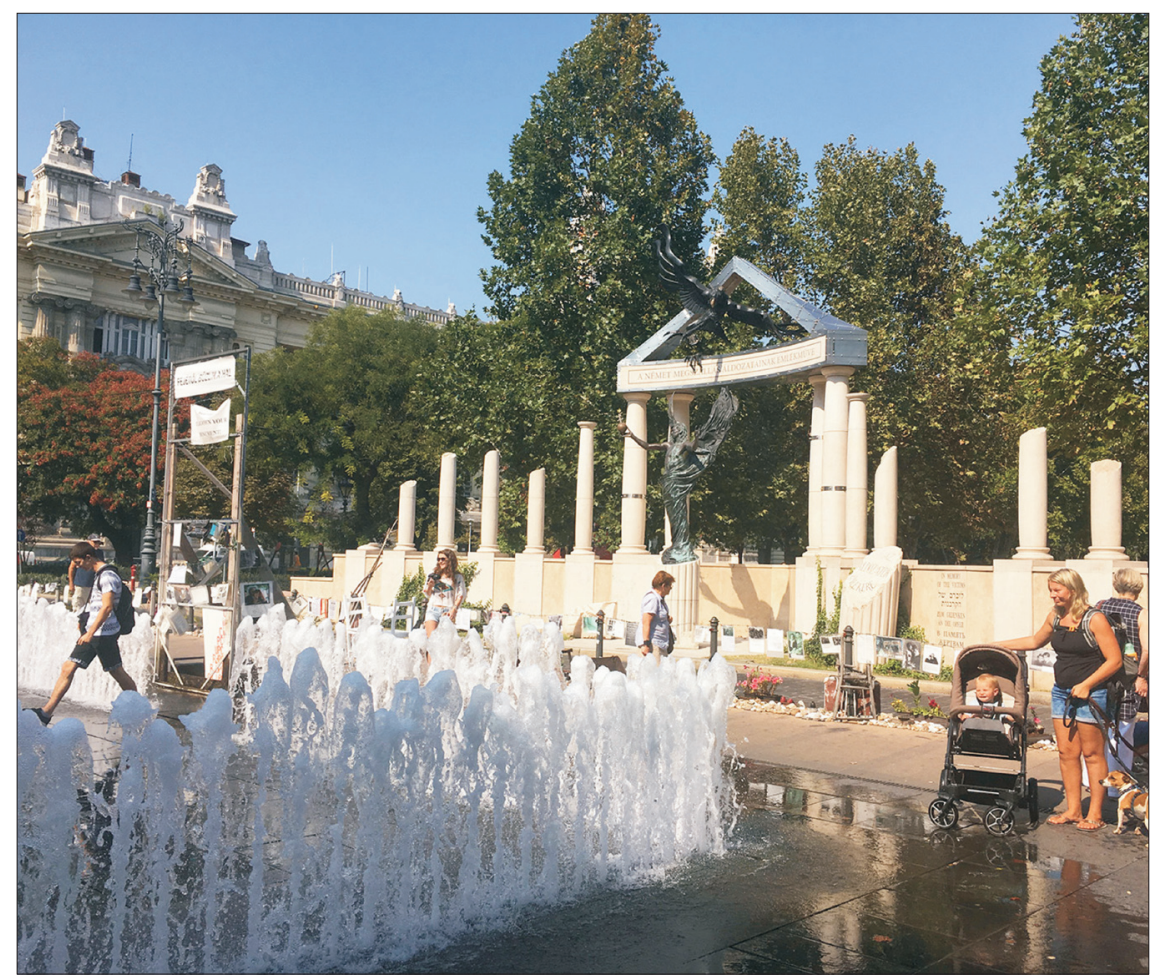

Photo 3. The monument, the counter-monument and the fountain. (Photo by the author) 


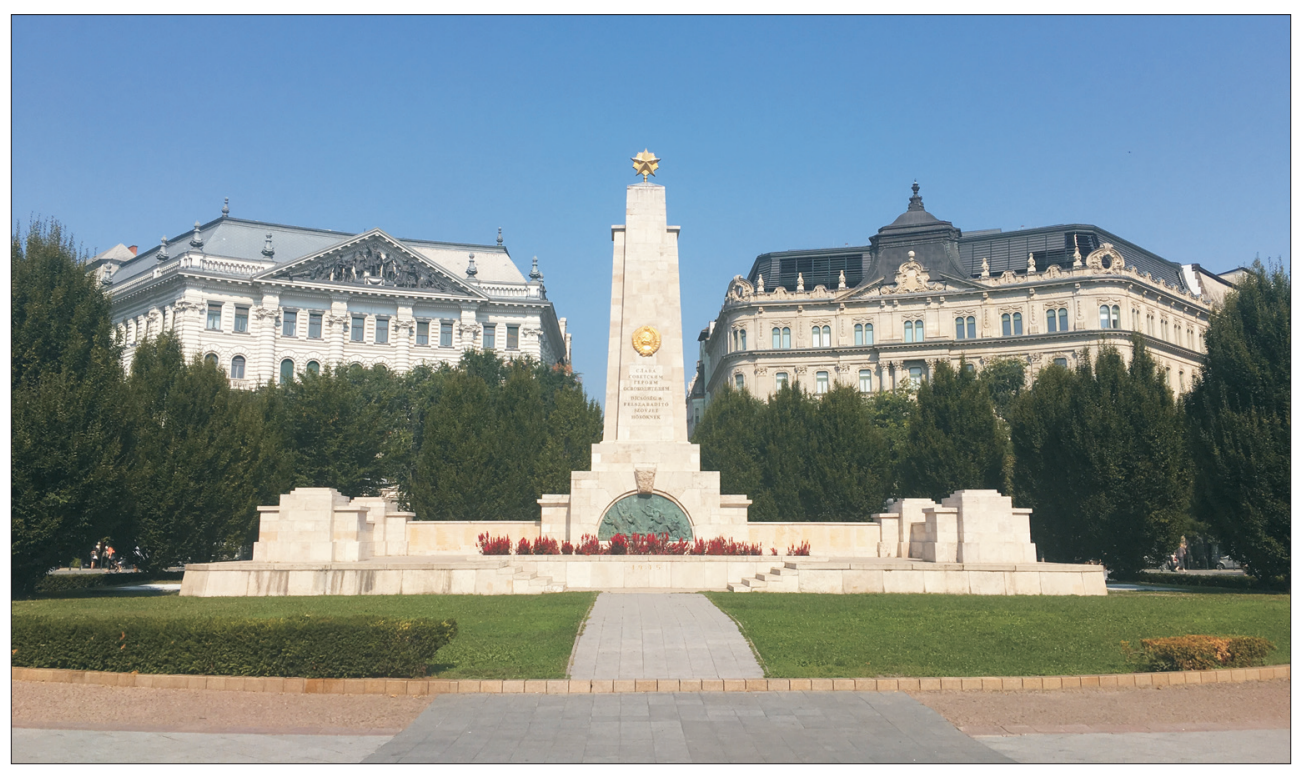

Photo 4. The monument dedicated to the Soviet soldiers died in World War II, standing on the northern side of the Liberty Square. (Photo by the author)

of abstract postmodernism and traditional figurative statues are equally present. Their reception by the public has been usually controversial, but, primarily, the latter ones are quite well accepted, some even became popular among locals and tourists (Fооте, K. et al. 2000, 316-317; LegÁt, T. 2013). In the reception of a monument by the public, both aesthetics and design tend to be important. It is especially true for the memorials of national importance, where the "poetics of presentation", especially in the case of an abstract design, "elicited public opposition as unfitting to represent the monument's commemorative theme" (AzAryahu, M. 2011, 130-131).

The monument of the victims of German occupation is not abstract in its design, yet it provoked public opposition, and not only because of the interpretation and narrative it broadcasts but also for being too didactic, basically an aesthetic catastrophe. The composition adopts figures easy to decode, but the comprehension is further enhanced by inscriptions. Such didactic design in public art is rather out-dated: since the 1970s and 1980s non-figurative compositions have been frequently used in public sculptures and monuments as well (Young, J.E. 2000). Furthermore, as it was briefly outlined previously, recent trend in monument building supports the idea to move closer to people, as ,for instance, the Reagan statue on the Liberty Square intend to do so. On the contrary, the monument dedicated to the German occupation is hanging "in between": with the eagle on top of the seven meters tall tympanum and Gabriel standing in an inaccessible position from pedestrians the composition stands in higher and further position, making it way too difficult to engage with (CzenkLI, D. 2014).

The columns and the tympanum refers to the classical, 19th century iconography of monument building, while the androgen figure of Gabriel looks more modern resulting in a confused design. As the respected sculptor, György Jovánovics summarised: “This is not an up-to-date work. (...) Viennese neo-baroque mixed with social realistic kitsch (...). The symbolism and message of it, which was clearly conceived to serve political order, is 
a messy nightmare" (Földes, A. 2014). These words are in harmony with Emilia PALONEN's assessment analysing the National Theatre built during the first Fidesz government: she concludes that it "aims to offer answers and capture meanings rather than playing with abstractions and, as Rév describes, its form is drinkable lemonade, easy for people to understand. (...) The elements of kitsch and historicism were typical of this style. (...) However, the monument on Liberty Square wishes to narrate one specific period of the country's history not the meaning of nation, the following argument perfectly describes the case of Liberty Square monument as well: "Rather than opening space for thoughts, it closes it, gives content to the national identity and values - similar to the way in which the architect was chosen in disregard of artistic competition, which indicates the need of Fidesz to prescribe national values" (Palonen, E. 2013, 547-548).

\section{"Falsification of history": Critics on narration and symbolisation}

The fiercest debate concerned the very core of the monument: its message and the symbols that were chosen to depict the narrative. Hungary's history in the $20^{\text {th }}$ century is overloaded with national and individual traumas, many of which have remained untold or kept in silence (Kovács, É. 2001; Gráni, G. 2006; Braham, R.L. and Kovács, A. 2015). The role Hungary played in World War II, including the details and circumstances of German occupation or the Holocaust of Hungarian Jews, especially the role the Hungarian state and collaborators played in it, is one of those topics which is still not widely known and/or accepted by the wider society. Limited public discourse is reflected in the low number of public memorials commemorating the Holocaust (Foote, K. et al. 2000, 324). The problem can be distilled to one question: who is the victim and who is the perpetrator?

The state monument suggests that the evil eagle (Germany) is the perpetrator, while
Archangel Gabriel (Hungary) is an innocent victim, who lost her power (falling glob) during and under the reign of Nazi Germany. As a matter of fact, the deportations were launched only after the German troops occupied the country, but then, in a short period (three months) approximately 470,000 Jews (and other victims, like Roma) were evicted and deported to death camps, with active assistance of the Hungarian authorities and civilians (UnGVÁRY, K. 2014). Not to mention, that during the Horthy era, Jews were systematically and gradually stripped off their civil rights: the first numerus clausus law was adopted as early as 1920 while labour service (forced labour performed by primarily Jewish men who suffered brutal and cruel treatment of Hungarian gendarmes and army officers) was institutionalised in 1939, years before the Nazis marched into Budapest (LALONDE, I. 2014; Ретнó, T. 2014; Ungváry, K. 2014).

In form of an open letter leading historians clearly pointed out why the interpretation of history cast in stone in the monument is unacceptable: "the monument is based on a falsification of history, it cannot serve its [alleged] function. By presenting the victims of the Holocaust and the collaborators as a single victim, it insults the memory of the victims" (Horváth, S. 2015). As Krisztián Ungváry commented: the monument's symbolism and the political intention behind it tries to "whitewash" Hungary's role in the Jewish Holocaust in Hungary (Ungváry, K. 2014). The monument not only blends together victims and perpetrators, but as protesters argued, by presenting the imperial eagle, a traditional German symbol, as perpetrator, it "shifts the blame further onto present Germany. However, the artist fails to represent the responsibility of the Hungarian state" . $^{\prime \prime}$

The public outcry was fuelled by the circumstances under which the decision-making process was conducted in a non-transparent clandestine way. For opponents of the government, taking into consideration

\footnotetext{
${ }^{8}$ The Living Memorial and theSzabadság Square resistance. http://www.silentheroes.eu/attachments/02/04_01/ LivingMemorial_PRESS.pdf
} 
the importance of such a monument commemorating a controversial and traumatic part of the country's history, a government decree issued on the last day of 2013 as a topdown decision (Newton, C. 2014; Horváth, S. 2015) was perceived as an example of the anti-democratic and cynical abuse of power and offensive symbolic politics driven by the governing party (FEHÉr, M. 2014c). Moreover, political analysts also criticised the timing of the construction (only few month before the parliamentary elections due on $6^{\text {th }}$ April 2014). Even though the winning position of Fidesz seemed certain, to secure it the monument could have been used to convince some voters from far-right Jobbik. The Jobbik, the third most powerful political party in the country, welcomed the construction. However, they insist on removal of Soviet monument at the same time?.

\section{Outline of history of the protest}

As the plan of the monument was revealed to the public, it instantly stirred up objection inside and outside the country. The protest activity - based on the level of institutionalisation - can be divided into three periods.

Between January and March 2014, national and international organisations, politicians, and historians issued open letters in press to express their objections. For instance, the Federation of Hungarian Jewish Communities criticized the plan as - in their view - it depicts Hungary as a victim of Nazi occupation, the symbolism of the statue seems downgrading the responsibility of Hungary, although it was an ally of Germany before and during World War II. Almost all Jewish representatives in the US Congress signed a letter in which they call attention that Jewish community in Hungary should participate in the decision how to remember their suffering during the Nazi occupation (FEHÉr, M. 2014b).

\footnotetext{
${ }^{9} \mathrm{http}: / /$ www.economist.com/news/europe/21595515row-about-statue-reignites-controversy-over-nazioccupation-statue-limitations
}

Prime Minister Viktor Orbán in his response highlighted that the planned monument was not a Holocaust memorial, but it is rather to pay tribute to the sufferings of both Jews and non-Jews during the war (Sокоц, S. 2014). He also stated that the monument was supposed to emphasise that when the Nazi military took the control over the state on $19^{\text {th }}$ March 1944, Hungary lost its sovereignty and was limited in decision making. He did not dispute that the Hungarian political elite collaborated with the Nazi, but as he wrote "there would have been no deportations without the German occupation, no wagons and no loss of hundreds of thousands of lives" (FeHér, M. 2014b). In media close to the government the monument was primarily perceived as a memorial wish to remind to the loss of sovereignty of the country (BorókAI, G. 2014). Germany expressed concerns, when noticed that "the actual decision about the monument was made very quickly and without wider debate"10.

A new form of protest emerged on $23^{\text {rd }}$ March. A flashmob, titled "Living memorial-my history" was organised by artists, philosophers, sociologists, curators, civic activists, many of them involved in previous anti-government protests. According to the invitation published on Facebook, attendees were asked to bring personal items "and place their own sacred symbols - a symbol of willingness to repent and to forgive - onto this unsought gravestone of our history"11. Hundreds of people participated actively in the flashmob, bringing artefacts and establishing the first elements of the countermonument, later called Living Memorial.

The second phase of the protest was marked by specific dates: it started on $8^{\text {th }}$ April, when the construction of the monument was relaunched and lasted until $20^{\text {th }}$ July when it was finalised. That nearly four months can be considered as the most active period of the protest: every day a group of protesters

\footnotetext{
${ }^{10}$ http://hvg.hu/itthon/20140122_A_nemet_ nagykovetsegnek_is_van_mondanival

${ }^{11}$ http://www.silentheroes.eu/attachments/02/04_01/ LivingMemorial_PRESS.pdf
} 
were present taking care of the items of the ever-growing counter-monument and regular cultural events were organised.

Beginning on $20^{\text {th }}$ July 2014, the third phase entailed as institutionalisation of ostensibly popular protest. Since spring of 2014, the counter-monument on Liberty Square has become a fixture of the cityscape. Similarly, the activist groups grown out of the protest are also regularly present not only on Liberty Square, but on the activist scene in Budapest as well. One group, called Eleven Emlékmü - az én történelmem (Living Memorial - My history) organises public discussions in topics like politics of memory, actual political or social issues. The activity of Szabadságszínpad (Freedom Stage) focuses on taking care of the counter-monument but they also arrange cultural and commemorative events (HEGYI, D. 2015, 87). Both groups are engaged in civic activism and charity. For instance, they commemorated the $100^{\text {th }}$ anniversary of Armenian Genocide, organised donations to the refugees in the summer of 2015 or joined numerous protests of teachers and health-care workers in 2015-2016.

\section{The iconography of the counter- monument}

The counter-monument, named Eleven Emlékmü (Living Memorial), was established on $23^{\text {rd }}$ March when the first personal artefacts were placed in front of the construction site. It is an ever-evolving composition made up by personal relics, like family photos, hand-written family stories, eviction notices, personal belongings, stones (some indicating the date and place when and from where the given person/family was transported to concentration camp) (Photo 5a,b).

Before $20^{\text {th }}$ July 2014, such artefacts were placed around the construction site. Each and every piece of the counter-monument was installed by activists over and over again every morning. Since the finalisation of the statemonument the installation has a stable position: the items are distributed on a narrow section of the pavement facing the official monument.
Next to the personal relics, two white chairs are essential part of the counter-monument. According to the creators' (among many others: György Jovánovics, András Rényi, Szabolcs Kisspál) intention the chairs facing each other are invitations for discussion: anybody is welcome to enter the discussion about the monument, the protest or that part of the history (Hegri, D. 2015, 84-85) (Photo 6).

Holocaust survivors and their relatives shared memories during the daily events, joined by historians, artists or activists. The major point was to open a discussion, a discussion which had not happened before the construction of the monument. Thus, the purpose of the counter-monument was to offer a narrative of the history of the German occupation different from that represented by the state-monument. As Péter Béndek phrased in his speech during the first flashmob when asked fellow-citizens "to tell, to share their family memory holds or remembers about our shared past" (HEGYI, D. 2015, 81).

In fact, the counter-monument is an everchanging assemblage of printed and handwritten papers, inscribed stones, photos, and two chairs. Furthermore, - as "living" items - the counter-monument is enriched with plants and flowers which can be understood as symbols for life and the living. Daily routines like watering and nurturing the plants or lightning candles can be considered as activities to keep alive the memory, so as the Living Memorial itself. Also, as AzAryahu noticed in the case of Kikar Rabin in Tel Aviv (Azaryahu, M. 1996, 507), such ritual activities might contribute to the institutionalisation of the unofficial memory site. This is in stark contrast to the static character of the state-monument and its version of frozen memory; cast in stone, this frozen memory is rigid in form and oblivious of personal and familial memories.

The counter-monument challenges the official monument with its content/message and aesthetics as well. By showing personal items, letters, family photos it brings the focus to the individual perspective of the events clearly challenging and, thus, subverting the authority of the official monument. Regarding the aes- 


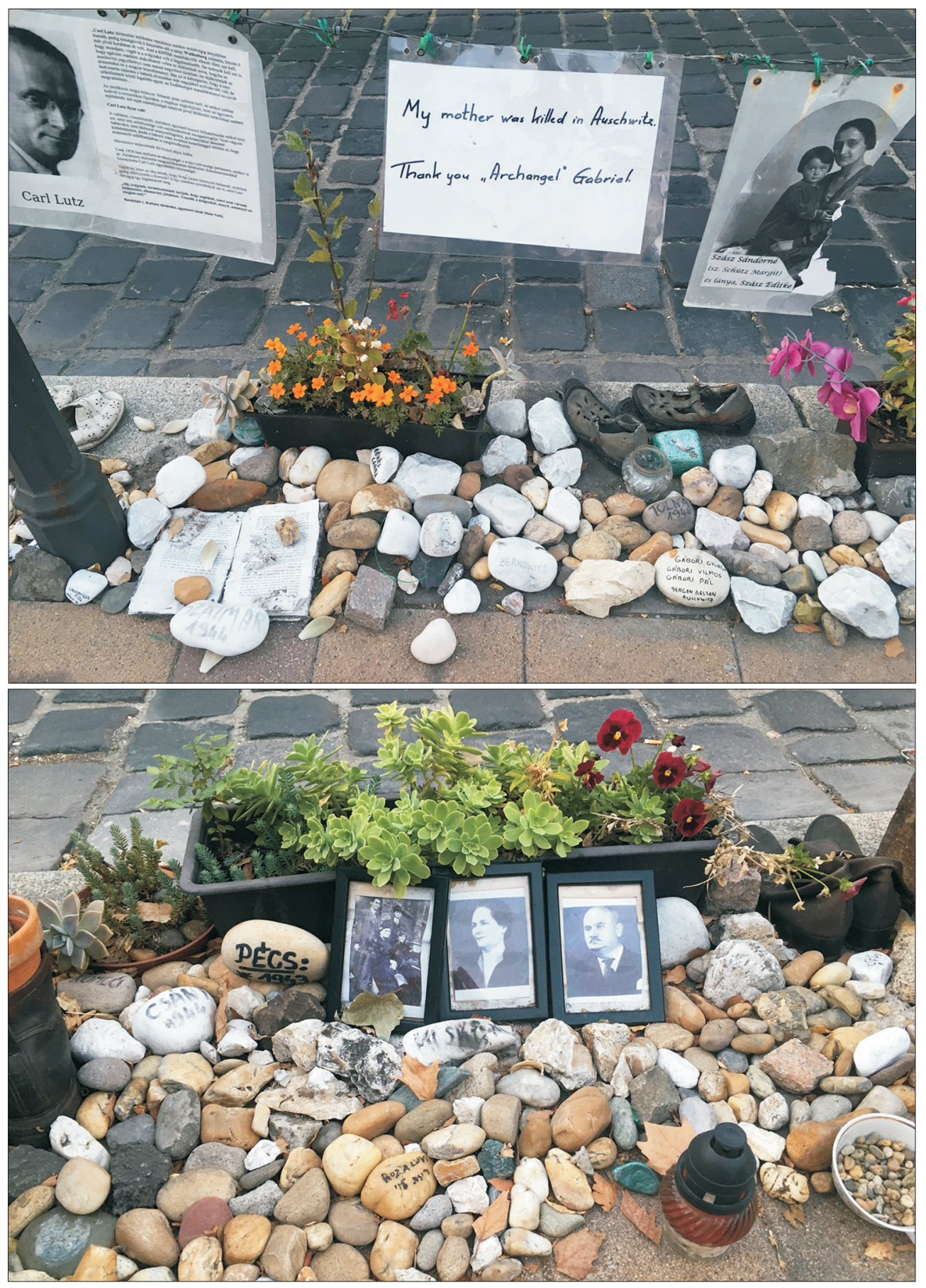

Photo $5 a, b$. The counter-monument (Living Memorial) compiled from personal relics, items and texts. On Photo 5a the handwritten paper says in English: "My mother was killed in Auschwitz. Thank you Archangel Gabriel". (Photo by the author) 


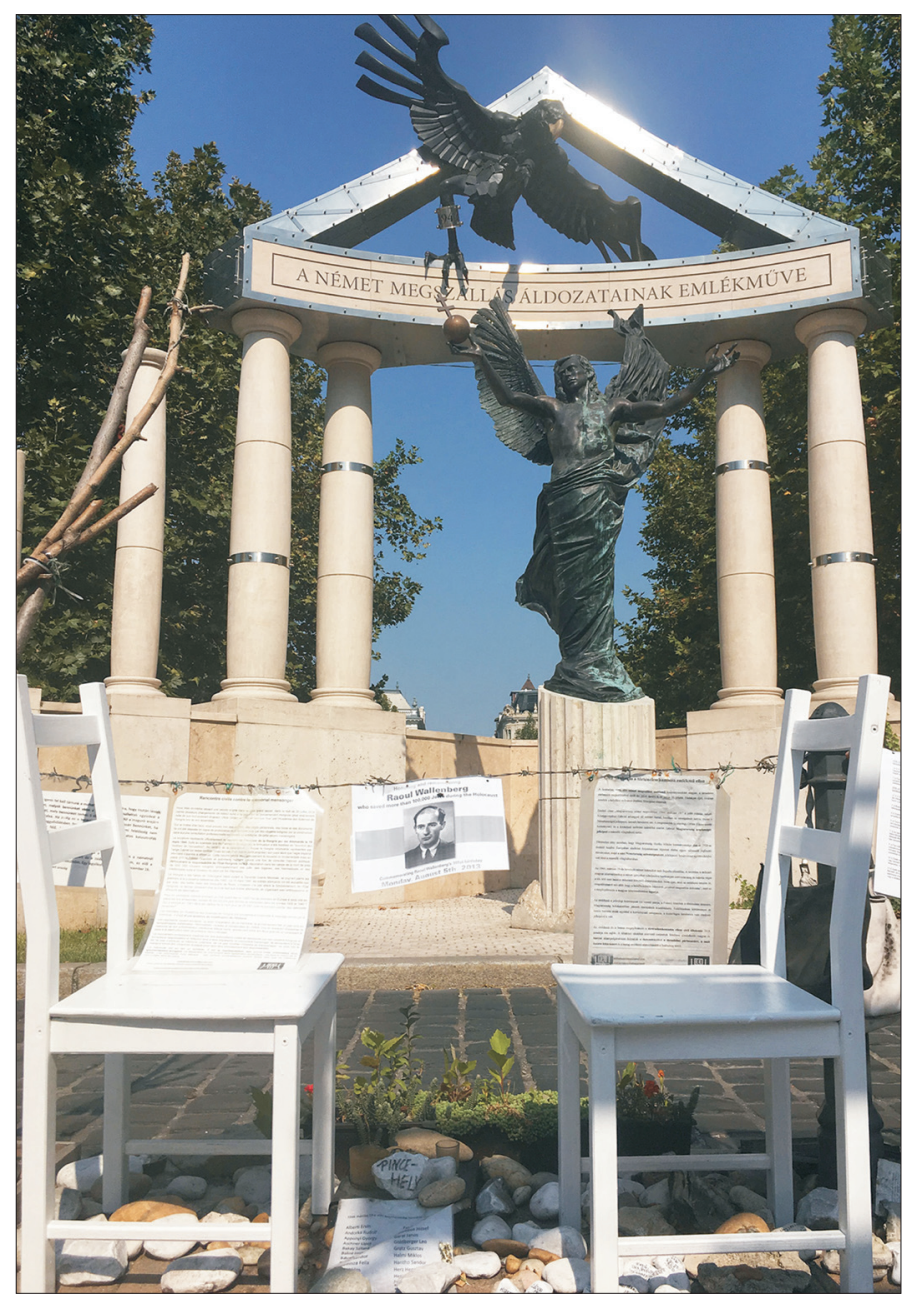

Photo 6. Two white chairs in the installation inviting for discussion. (Photo by the author)

thetics the official monument applies simplistic symbolisation and conventional metaphors (e.g. angel, eagle) while the family memories, diaries, personal belongings serve as unique testaments, inviting the visitor to spend time there and engage with the items (Photo 7).

Furthermore, the counter-monument is in constant motion: anyone can touch and add new pieces or leave messages. The tangible character further stress out the striking difference with the official monument which stands on the other side of the road oddly squeezed in a tiny spot, impossible to touch, or even step close to.

Moreover, the Living Memorial is not only alive because of the personal items and flowers it includes: it has a personality, as activists are ready to inform or start a conversation about the monument and the protest with the visitors, including foreigners: short description is available about the protest on the spot in more languages including English, German, Hebrew, Russian, French and Hungarian languages (Photo 8). 


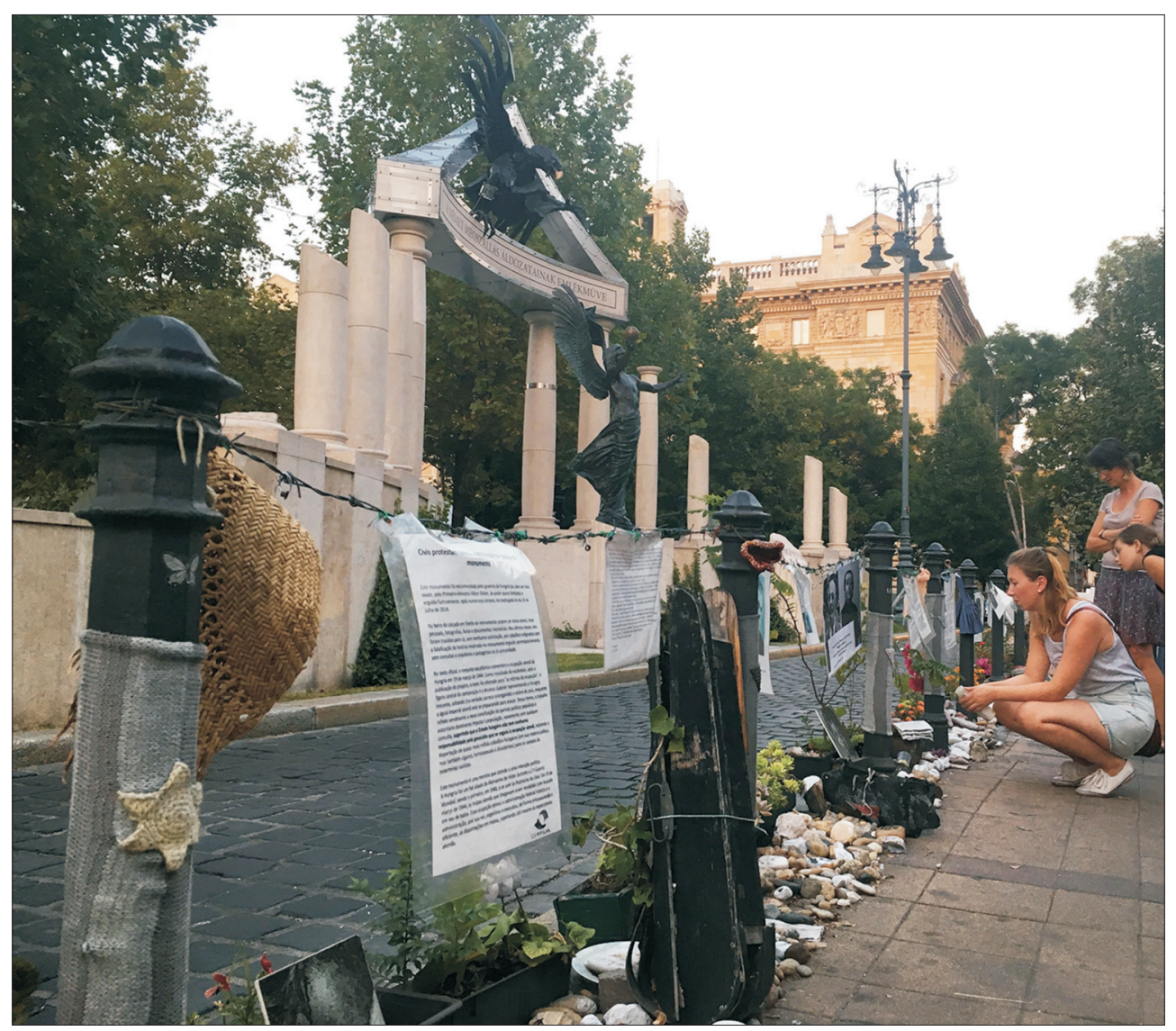

Photo 7. Visitors in front of the counter-monument. (Photo by the author)

Altogether, the Living Memorial on Liberty Square can be perceived as an adequate example of a counter-monument: while the official monument is a clichéd, artistically outdated composition, installed as a result of a top-down political decision, the juxtaposed Living Memorial - compiled from constantly enriched relics - has a human, personal and tangible character. The memorial born as a result of a bottom-up initiative, due to narratives broadcasted by the commemorated persons' individual stories invites to interaction and creates a connection between past and present (which would be the major purpose of any monument) strengthened by the presence of activists.

\section{Concluding remarks}

If we accept Nelson and Olin's argument, a monument's social relevance and vitality is correlated with their capacity "to coalesce communal memories and aspirations" (Nelson, R.S. and Olin, M. 2003, 6), the statemonument dedicated to the victims of the German occupation is a failure. The composition, besides its weird and utterly unfortunate spatial position and highly questionable aesthetic value, represents a narrative, which is not only misguiding, but is based on dubious interpretations of the past. Instead of opening a discussion to come to terms with the traumas the nation went through 


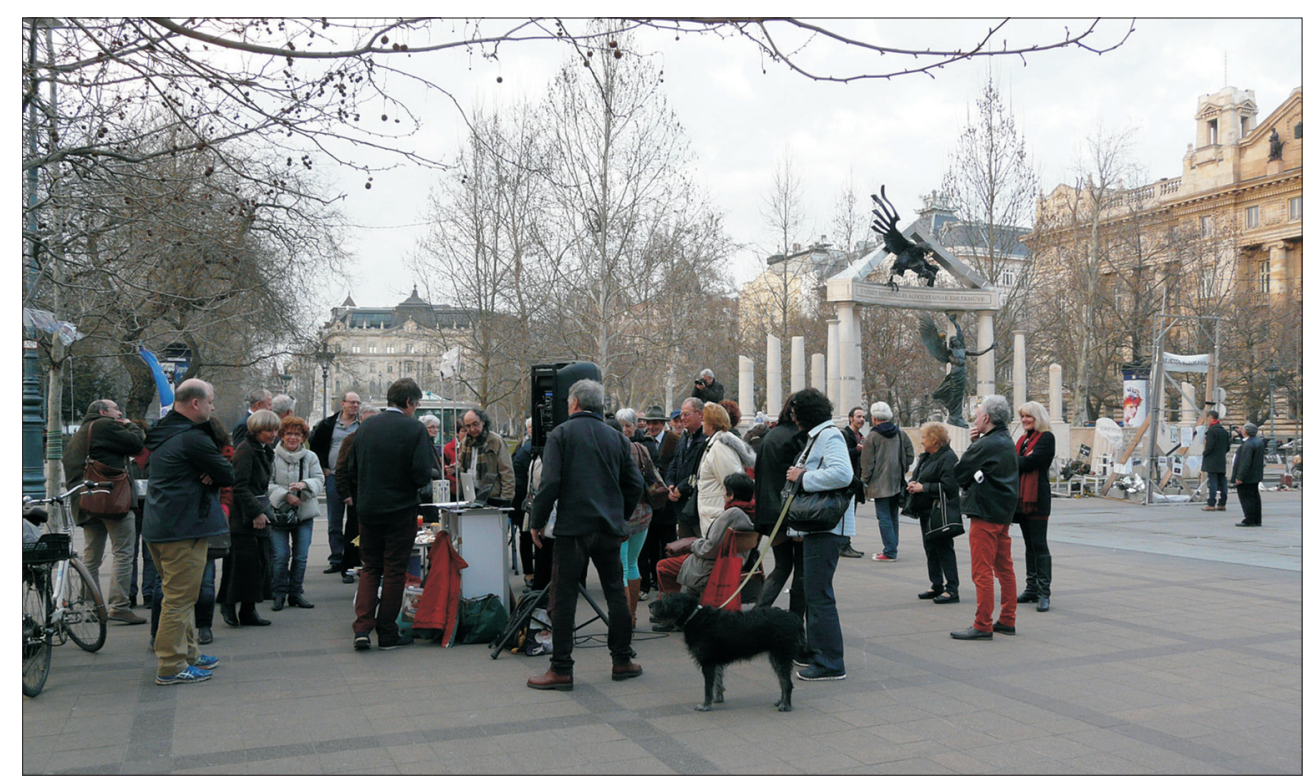

Photo 8. One of the regular afternoon events of Activists of Freedom Stage. (Photo by the author)

in World War II, it represents a blurred vision of victimhood, without intention to practice self-criticism and exempts the state from responsibility further procrastinating the long-time necessary public discussion and memory work.

However, since there was no unveiling ceremony and no official commemorative event took place there, the monument failed to become part of the political landscape of power, which has been important element of political agenda of the governing Fidesz party. Interestingly enough, the attempt of the government to inscribe its power to the space in a square already charged with symbolic traditions and meanings, resulted in complex and partially unintended consequences: it gave birth to a counter-monument and induced vivid, power critical civic activism.

The counter-monument, as a testament of victims, is in an intensive, dialectic relationship with the official one: the mixture of personal relics, the presence of activists, the regular events embodies what is missing from the monument: it is visible, accessible, tan- gible, alive and ever-changing. Nevertheless, I would like to call attention to the paradoxical nature of the relationship between the monument and the counter-monument. Even though the original purpose of the activists was to prevent the construction of the monument, actually, the official monument is the one that justifies the presence of the protest while the existence of the counter-monument keeps alive/protects the official monument from oblivion. At the time of writing that protest is the longest prevailing continuous anti-government action in Hungary with a more than two year long history.

To conclude, the state monument - neglected by its creators and rejected by the opponents of the government - offered opportunity for a group of civilians to gain visibility and develop a successful activist forum. In addition, the Liberty Square, charged with a long tradition of continuously rephrased meaning of liberty, is filled with the spirit of protest once again. 


\section{REFERENCES}

Azaryahu, M. 1996. The Spontaneous Formation of Memorial Space. The Case of Kikar Rabin, Tel Aviv. Area 28. (4): 501-513.

Azaryahu, M. 2011. Public controversy and Commemorative Failure: Tel Aviv's Monument to the Holocaust and National Revival. Israel Studies 16. (1): 129-148.

BoróKAI, G. 2014. História vagy hisztéria? (History or histery?). http://valasz.hu/publi/historia-vagyhiszteria-75577. Accessed: 10.08.2014.

Braham, R.L. and Kovács, A. 2015. A holokauszt Magyarországon hetven év múltán: történelem és emlékezet. (The Holocaust in Hungary after seventy years: history and memory). Budapest, Múlt és Jövő, 287.

CZEnKLI, D. 2014. György Péter a Szabadság téri szoborról (Péter György's opinion about the monument in Liberty Square). http://magyarnarancs.hu/kultura/gyorgy-peter-a-szabadsag-teri-szoborrol-91023. Accessed: 11.08.2014.

DöмӧтӧRғI, T. 1991. Az országzászló-mozgalom, 1921-1944 (The national banner movement, 1921-1944). Élet és Tudomány 46. (8): 232-234.

Fenér, M. 2014a. US Urges Dialogue on Hungary's Controversial Nazi Occupation Monument. http:// blogs.wsj.com/emergingeurope/2014/04/22/usurges-dialogue-on-hungarys-controversial-nazioccupation-monument/. Accessed: 10.08.2014.

FeHÉr, M. 2014b. Jewish U.S. Congressmen Urge Hungary PM To Reconsider Nazi Occupation Monument. http:// blogs.wsj.com/emergingeurope/2014/04/22/ usurges-dialogue-on-hungarys-controversial-nazi-occupation-monument/ Accessed: 10.08.2014.

FeHÉR, M. 2014c. Hungarian Sculptor Defends Monument to Victims of Nazis Monument Serves to Reconcile Jewish and Non-Jewish Hungarians, Sculptor Says. http://online.wsj.com/articles/hungarian-sculptor-defends-monument-to-nazi-occupation1406910612. Accessed: 10.08.2014.

FöLDES, A. 2014. A megszállási emlékmü: köztéri merénylet (The occupation monument: assassination on public space). http://index.hu/belfold/2014/01/21/rohamtempoban_keszul_a_nemet_megszallasi_emlekmu/. Accessed: 10.08.2014

Foote, K. and Azaryahu, M. 2007. Toward a Geography of memory: Geographical dimensions of public memory and commemoration. Journal of Political and Military Sociology 35. (1): 125-144.

Foote, K., Tóth, A. and Árvay, A. 2000. Hungary after 1989: Inscribing a new past on place. The Geographical Review 90. (3): 301-334.

Gregory, D., Johnston, R., Pratt, G., Watts, M. and Whatmore, S. eds. 2009. The Dictionary of Human Geography, th $^{\text {th }}$ Edition. London, Wiley-Blackwell.

GYÁnI, G. 2006. Memory and Discourse on the 1956 Hungarian Revolution. Europe-Asia Studies 58. (8): 1199-1208.
Hegri, D. 2015. Turning a non-place into a place: An interview by Dóra Hegyi with members of the Living Memorial. In War of memories. A guide to Hungarian memory politics. Eds.: Hegry, D., LÁszLó, Zs. and Leposa, Zs. Budapest, Tranzit.hu. 79-104.

Новзвашм, E. 2015. Introduction: Inventing traditions. In The Invention of Tradition. Eds.: Новsваwм, E. and Ranger, T., Cambridge, Cambridge University Press, $1-14$.

HoRváth, S. 2015. Goodbye Historikerstreit, Hello Budapest City of Angels: The Debate about the Monument to the German Occupation. http://www.cultures-of-history. uni-jena.de/debates/hungary/goodbye-historikerstreit-hello-budapest-city-of-angels-the-debate-aboutthe-monument-to-the-german-occupation/\#fn-text14 Accessed: 08.09.2016.

KovÁcs, É. 2001. A terek és a szobrok emlékezete (1988-1990) - Etűd a magyar rendszerváltó mítoszokról (Memory of spaces and statues [1988-1990] - An etude about the myths of Hungarian transformation). Regio 12. (1): 68-91.

Lalonde, I. 2014. Hungarian government green-lights controversial memorial to "victims of German invasion". http://budapestbeacon.com/featured-articles/ hungarian-government-green-lights-controversialmemorial-to-victims-of-german-invasion/. Accessed: 10.08.2014.

Legát, T. 2013. "Valahol el kell mondani az ünnepi beszédet" - Pótó János történész köztéri szobrainkról. ("Ceremonial speeches need to be delivered somewhere" - Historian János Pótó about our statues in public spaces.) http:// magyarnarancs.hu/lokal/kozteri-szobrok-poto-janostortenesz-85690. Accessed: 10.09.2016.

Light, D., Nicolae, I. and Suditu, B. 2002. Toponymy and the Communist City: Street names in Bucharest, 1948-1965. GeoJournal 30. 135-144.

Nelson, R.S. and Olin, M. 2003. Introduction. In Monuments and memory, made and unmade. Eds.: Nelson, R.S and Olin, M., Chicago and London, The University of Chicago Press, 1-10.

Newton, C. 2014. How should Hungarians remember World War II? http://www.aljazeera.com/indepth/ features/2014/05/how-should-hungarians-rememberworld-war-ii-201452565251358783.html

Nolan, D. 2014. German occupation memorial completed under cover of darkness. http://budapestbeacon.com/ public-policy/german-occupation-memorial-completed-under-cover-of-darkness/ Accessed: 10.08.2014.

NorA, P. 1989. Between Memory and History: Les Lieux de Mémoire. Representations 26. Spring, $7-24$.

Orbán, V. 2013. A kormány nemzeti gazdaságpolitikát folytat (The government pursues national economic policy). XXIV. Bálványosi Nyári Szabadegyetem és Diáktábor, Tusnádfürdő. XXIV Summer University and Student Camp, Băile Tuşnad, Romania. http://2010-2015.miniszterelnok.hu/beszedek/280/). Accessed: 11.09.2016 
Palonen, E. 2008. The city-text in post-communist Budapest: street names, memorials, and the politics of commemoration. GeoJournal 73. (3): 219-230.

Palonen, E. 2012. Transition to Crisis in Hungary: Whistle-Blowing on the Naked Emperor. Politics \& Policy 40. (5): 930-957.

Palonen, E. 2013. Millenial politics of architecture: myths and nationhood in Budapest. Nationalities Papers 41. (4): 536-551.

Pásztor, T. 2014. A náci megszállás szobra. (The statue of Nazi occupation). http://pasztortibor.blog. hu/2014/01/19/naci_megszallas_szobra. Embedded link in blog: Mayor Antal: Rogán's proposal to the session of the body of representatives, T-28/2014, 19 January 2014; letter of János Lázár to Antal Rogán, 17 January 2014. The description of the work is not dated. The advisory opinion is dated 15 January 2014. https://docs.google.com/ file/d/0B4gcb6t1VP3eRHU2U0dRWFgzQTQ/edit. Accessed: 08.09. 2016.

Ретно̋, T. 2014. Catharsis warded off Controversy over monument of victims of Hungary's German occupation and House of Fates. http://www.budapesttelegraph. com/news/627/ catharsis_warded_off_controversy_over_monument_of_victims_of_hungary's_german_occupation_and_house_of_fates. Accessed: 10.08.2014.

Rose-Redwood, R.S. 2008. "Sixth Avenue is now a memory": Regimes of spatial inscription and the performative limits of the official city-text. Political Geography 27. (8): 875-894.

SHANKEN, A.M. 2002. Planning Memory: living memorials in the United States during World War II. The Art Bulletin 84. (1): 130-147.

SокоL, S. 2014. German occupation statue in Budapest not a Holocaustmemorial, says Orban. http://www.jpost.com/ Jewish-World/Jewish-Features/German-occupationstatue-in-Budapest-not-a-Holocaust-memorial-saysOrban-355939. Accessed: 10.08.2014

Stevens, Q., Franck, K.A. and FazaKerley, R. 2012. Counter-monuments: the anti-monumental and the dialogic. The Journal of Architecture 17. (6): 951-972.

StraKosch, E. 2010. counter-monuments and NationBuilding in Australia. Peace Review: A Journal of Social Justice 22. (3): 268-275.

TILL, K. 1999. Staging the Past: Landscape designs, cultural identity and Erinnerungspolitik at Berlin's Neue Wache. Cultural Geographies 6. (3): 251-283.

UnGVÁRY, K. 2014. Az eleven borzalom (The living horror). http://hvg.hu/velemeny/20140121_Az_eleven_ borzalom. Accessed: 10.08.2014.

VÁrnagy, R. 2015. Hungary. European Journal of Political Research Political Data Yearbook 54. (1): 133-140.

Young, J.E. 2000. At memory's edge. New Haven and London, Yale University Press.

Zeidler, M. 2009: A revíziós gondolat (The revisionist thought). Bratislava, Kalligram.

\section{OTHER SOURCES}

http://latogatokozpont.parlament.hu/en/a-kossuthter-leirasa

565/2013 (XII. 31.) Government decree. Magyar Közlöny/Hungarian Bulletin. 2013. 225. 13. http:// www.kozlonyok.hu/nkonline/MKPDF/hiteles/ mk13225.pdf. Accessed: 10.08.2014.

The Living Memorial and the Szabadság Square resistance. http://www.silentheroes.eu/attachments/02/04_01/ LivingMemorial_PRESS.pdf

http://www.kormany.hu/hu/miniszterelnokseg/hirek/ nem-lesz-avatounnepseg

In the middle of the night, Hungary sets up disputed memorial to 1944 German Occupation. http://www. foxnews.com/world/2014/07/20/in-middle-nighthungary-sets-up-disputed-memorial-to-144-german-occupation/. Accessed: 10.08.2014.

Amid protest, building of controversial WWII statue begins in Budapest. http://www.jta.org/2014/04/08/newsopinion/united-states/amid-protest-building-ofcontroversial-wwii-statue-begins-in-budapest. Accessed: 09.09.2016.

Statue of limitations. A row about statue resignites controversy over te Nazi occupation. http://www.economist. com/news/europe/21595515-row-about-statue-reignites-controversy-over-nazi-occupation-statuelimitations. Accessed: 10.08.2014

A német nagykövetségnek is van mondanivalója a Szabadság téri emlékmüról. (The Embassy of Germany also has a comment on Liberty Square monument. http://hvg. hu/itthon/20140122_A_nemet_nagykovetsegnek_ is_van_mondanival Accessed:10.08.2014. 